\title{
Predictors of Mortality in Acute Kidney Injury Patients in an Intensive Care Unit: Is Hemodialysis No Good?
}

\author{
Habib Md Reazaul Karim ${ }^{1}$, Chinmaya Kumar Panda ${ }^{2}$ \\ Indian Journal of Critical Care Medicine (2019): 10.5005/jp-journals-10071-23243
}

Sir,

Acute kidney injury (AKI), prevalent in critically ill patients, is multifactorial and is associated with increased morbidity and mortality even in recent days. ${ }^{1,2}$ Knowing the factors associated with mortality in patients with AKI in the intensive care unit (ICU) patients are likely to help us in decision making and better management of such patients. In this line, we read the article on predictors of mortality in acute kidney injury patients admitted to medical intensive care unit by Saxena $A$ et al. $^{2}$ The report highlights many relatively less known facts in Indian scenario; however, we feel one interesting fact/finding needs further clarification.

The authors Saxena A, Meshram SV² have found that the use or non-use of hemodialysis (HD) was not associated with decreased or increased in-hospital mortality among the cohort. In this aspect, we feel a few facts need to be considered. One of the critical factors which is considered in context to dialysis-related mortality is 'dialysis adequacy. ${ }^{3}$ The adequate duration of dialysis, appropriate clearances of solutes, hemoglobin levels in dialyzed patients, etc. plays a vital role in this aspect. ${ }^{3}$ The magnitude of change in serum creatinine between admission and initiation of renal replacement therapy (RRT) has also been shown to be associated with outcome (i.e., mortality). ${ }^{4}$ The authors Saxena A, Meshram SV ${ }^{4}$ increased serum creatinine at the diagnosis of AKI and increased the difference between the peak value within 48 hours of diagnosis and at the diagnosis was significantly associated with increased mortality. ${ }^{2}$ The authors have also found that metabolic acidosis and hyperkalemia were significantly associated with increased mortality. As effective RRT is also capable of managing both the conditions, the inability of HD to reduce mortality in the cohort puts a question mark on the HD adequacy again. Moreover, an absolute higher creatinine concentration was associated with greater use of dialysis and is associated with decreased mortality. ${ }^{5}$

All these circumstances lead us to a few facts; what were the criteria used to determine the need and starting of RRT? Were the patients, those required RRT in survivor and nonsurvivor group
1,2Department of Anesthesiology and Critical Care, All India Institute of Medical Sciences, Raipur, Chhattisgarh, India

Corresponding Author: Habib Md Reazaul Karim, Department of Anesthesiology and Critical Care, All India Institute of Medical Sciences, Raipur, Chhattisgarh, India, Phone: 9612372585, e-mail: drhabibkarim@gmail.com

How to cite this article: Karim HMR, Panda CK. Predictors of Mortality in Acute Kidney Injury Patients in an Intensive Care Unit: Is Hemodialysis No Good? Indian J Crit Care Med 2019;23(9):439.

Source of support: Nil

Conflict of interest: None

similar in context to initial serum creatinine, $\mathrm{K}^{+}, \mathrm{pH}, \mathrm{AKI}$ and disease severity levels? Was the RRT equally efficacious among the survivor and nonsurvivors? Therefore, we feel that monitoring and analyzing these parameters would have given us a more explicit message.

\section{References}

1. Abd ElHafeez S, Tripepi G, Quinn R, Naga Y, Abdelmonem S, AbdelHadi M, et al. Risk, Predictors, and Outcomes of Acute Kidney Injury in Patients Admitted to Intensive Care Units in Egypt. Sci Rep 2017;7:17163.

2. Saxena A, Meshram SV. Predictors of mortality in acute kidney injury patients admitted to medicine intensive care unit in a Rural Tertiary Care Hospital. Indian J Crit Care Med 2018;22:231-237.

3. Locatelli F, Canaud B. Dialysis adequacy today: a European perspective. Nephrol Dial Transplant 2012;27:3043-3048.

4. Brar H, Olivier J, Lebrun C, Gabbard W, Fulop T, Schmidt D. Predictors of mortality in a cohort of intensive care unit patients with acute renal failure receiving continuous renal replacement therapy. Am J Med Sci 2008;335:342-347.

5. Wilson FP, Yang W, Feldman HI. Predictors of Death and Dialysis in Severe AKI: The UPHS-AKI Cohort. Clin J Am Soc Nephrol 2013;8:527537.

(0) The Author(s). 2019 Open Access This article is distributed under the terms of the Creative Commons Attribution 4.0 International License (https://creativecommons. org/licenses/by-nc/4.0/), which permits unrestricted use, distribution, and non-commercial reproduction in any medium, provided you give appropriate credit to the original author(s) and the source, provide a link to the Creative Commons license, and indicate if changes were made. The Creative Commons Public Domain Dedication waiver (http://creativecommons.org/publicdomain/zero/1.0/) applies to the data made available in this article, unless otherwise stated. 